\title{
PITUITARY PROLACTIN AND THE OESTROUS CYCLE OF SOWS
}

\author{
W. R. THRELFALL, C. E. MARTIN, H. E. DALE, R. R. ANDERSON \\ AND G. F. KRAUSE
}

Departments of Veterinary Medicine and Surgery and Veterinary Physiology, School of Veterinary Medicine, Department of Dairy Husbandry, College of Agriculture, and Department of Statistics, College of Arts and Sciences, University of Missouri, Columbia, Missouri 65201, U.S.A.

(Received 24th September 1971, accepted 22nd March 1972)

\begin{abstract}
Summary. Pituitaries of slaughtered sows were assayed for prolactin with the intradermal pigeon crop gland technique. Sows were classified into three groups-follicular, early postovulatory and luteal-after gross inspection of the ovaries. Pituitary prolactin was lowest in the postovulatory group (57.6 \pm 2.4 i.u.) and highest in the luteal group $(87.0 \pm$ 12.9 i.u.). This study indicated that the pituitary prolactin content in the sow was comparable with that reported for dairy cows and refutes previous reports of small quantities present in the swine pituitary.
\end{abstract}

\section{INTRODUCTION}

Prolactin was first reported to be lactogenic in swine by Stricker \& Grueter (1928), who were successful in stimulating milk secretion in swine by injections of crude pituitary extracts. Gardner \& Turner (1933) also induced lactation with ovine prolactin in one sow 15 days after parturition, though the possibility of other pituitary hormones being present in the ovine prolactin preparation was admitted by the authors.

Day, Anderson, Hazel \& Melampy (1959) measured pituitary prolactin throughout the oestrous cycle and pregnancy of thirty gilts. The assay technique was the intradermal pigeon crop test of Meites \& Turner (1950). The responses were recorded as $0,+,++$ and +++ with increasing sizes of proliferation. The increase in proliferation denoted an increase in the amount of prolactin present. However, standard preparations were not used for quantitative comparison. Although these investigators did not determine the number of international units present in each animal, they did report that the amount of hormone increased until oestrus, at which time it dropped to the lowest recorded value.

\section{MATERIALS AND METHODS}

Domestic pigeons of both sexes were acquired from the Steinhilber Company of Oshkosh, Wisconsin. The birds were approximately 10 months of age and 
weighed $310 \pm 40 \mathrm{~g}$. Purina Pigeon Checker Chow and water were given freely.

On the day before the start of the injection period, the birds were weighed and placed in separate cages. The mean weights were calculated for each treatment group, which consisted of three birds. Birds were grouped so as to maintain an approximately equal mean weight for all groups used during a given assay period.

Pituitaries were obtained from a local abattoir. The sows were stunned and then exsanguinated. After decapitation, the pituitary was removed and placed on ice. In the laboratory approximately $1 \mathrm{hr}$ later, the gland was weighed and frozen at $-40^{\circ} \mathrm{C}$ until the time of assay.

The previous history of the animals was unknown. Reproductive activity was assessed by gross inspection after the method of Day (1968). Pregnant sows were excluded. Non-pregnant sows were classified by the macroscopic appearance of their ovaries into three groups-follicular, early postovulatory (corpora haemorrhagica) and luteal. Each group contained ten animals.

The assay technique employed was that described by Grosvenor \& Turner (1958). Four daily injections were made intradermally over the crop sac, $\frac{3}{4}$ in. from the mid-line. A 25-gauge $\frac{1}{2}$ in. needle and a $0 \cdot 5$-ml tuberculin syringe were used. Each injection consisted of $0.1 \mathrm{ml}$ of the solution to be assayed and both crop glands were used on each bird.

On the day before the start of the injection schedule, the samples were homogenized in physiological saline so that the particles in the solution could pass through a 25-gauge needle. During each bioassay period, determinations were made both for standard sheep prolactin and for two dilutions of four unknowns. A group of pigeons which received only physiological saline and another group which received no injections served as controls for each assay. Only one preparation was injected into each of the individual groups.

Once removed, the crop sacs were split open and stretched over the $3 \cdot 5-\mathrm{cm}$ diam. mouth of a bottle. Equal tension was exerted at all points of the periphery of the different crop sacs; this was checked by visual inspection of the thickness of the structure and by an estimate of the elastic recoil. The bottle was held over a light source and responses were compared to circular brass rings which varied by $0.25 \mathrm{~cm}$ from 1.00 to $3.50 \mathrm{~cm}$. These were the same style rings used by Grosvenor \& Turner (1958). Responses were usually circular and could, therefore, be expressed as the diameter of a circle.

\section{RESULTS}

The three solutions of standard prolactin, $0.453,0.225$ and 0.113 i.u., gave responses that were proportional to the log of the dose within the response range $-1.78 \mathrm{~cm}$ to $2.47 \mathrm{~cm}$. These findings were in general agreement with those of Grosvenor \& Turner (1958). These authors, however, were able to achieve a linear log-dose response relationship up to $3.25 \mathrm{~cm}$ and also found that the amount of prolactin required to obtain a given response was approximately $25 \%$ of that necessary in this study.

An analysis of variance was calculated for comparison of the pooled standard responses to each of the three groups of sows. Comparisons were made to 
determine if the variations due to regression, different preparations or deviation from parallelism were significant. The analysis indicated that the variations due to regression and preparation were significant while the deviation from parallelism was not. This satisfied the criteria for a valid bioassay (Finney, 1964) and permitted further consideration of the data.

Utilizing a similar analysis of variance technique, the hormone content of each pituitary was calculated. Pituitary prolactin values for each of the ten animals in the three groups, the mean of each group, and the standard error of the means were computed. Sows in the follicular stage of the cycle had a pituitary prolactin content (mean \pm S.E.) of $72 \cdot 6 \pm 6 \cdot 6$ i.u. The early postovulatory group had a mean content of $57.6 \pm 2.4$ i.u., and the luteal group had a mean content of $87 \cdot 0 \pm 12 \cdot 9$ i.u.

The least significant difference (Snedecor \& Cochran, 1968) of the means was calculated to be 12.6 i.u. From the mean values of the three groups and the least significant difference of those means, it becomes evident that the pituitaries of animals within the early postovulatory group were significantly lower, and those of animals within the luteal group were significantly higher, in prolactin content than those of animals in the follicular stage.

\section{DISCUSSION}

The decrease in pituitary prolactin early after ovulation correlates with declining levels of oestrogen. The interrelationship of these hormones has been demonstrated by several investigators and oestrogen is acknowledged as important in the control of prolactin production and secretion. Nagasawa, Chen \& Meites (1969) and Voogt, Clemens \& Meites (1969) both demonstrated that the administration of exogenous oestrogen produced an increase in the amount of prolactin in the pituitary and blood of the female rat. Others (Reece \& Turner, 1936; Ratner, Talwalker \& Meites, 1963) did not measure serum levels of prolactin but found that oestrogen increased the pituitary content.

Compared to values reported for other species, the pituitary content of prolactin in swine was found to be quite high in the present investigation. The range of values is similar to that reported in cows (Bates, Riddle \& Lahr, 1935) and considerably above the amount in most experimental animals (Meites \& Turner, 1950). The findings presented here contrast rather sharply with the low values previously reported for swine by Bates et al. (1935) and Chance, Rowlands \& Young (1939).

The cyclic variations reported by Day et al. (1959) are similar to findings of this study. Both investigations estimated the stage of the ovarian cycle and grouped individuals into only three categories. The values reported by Day for the 2nd day of the cycle correspond approximately to the follicular group of this investigation and both are characterized by relatively low values. Day et al. (1959) also reported that the largest quantity of prolactin was present on Days 18 to 19; this would coincide with the high values in the luteal group of the present study. 


\section{REFERENCES}

Bates, R. W., Riddle, O. \& LahR, E. L. (1935) An assay of three hormones present in anterior pituitaries of seven types of cattle classified for age, sex and stage of reproduction. Am. F. Physiol. 113. 259.

Chance, M. R. A., Rowlands, I. W. \& Young, F. G. (1939) Species variation in thyrotrophic, gonadotrophic and prolactin activities of the anterior hypophyseal tissue. 7. Endocr. 1, 239.

DAY, B. N. (1968) Reproduction of swine. In: Reproduction in Farm Animals, p. 279. Ed. E. S. E. Hafez. Lee \& Febiger, Philadelphia.

Day, B. N., Anderson, L. L., Hazel, L. N. \& Melampy, R. M. (1959) Gonadotrophic and lactogenic hormone potencies of gilt pituitaries during the estrous cycle and pregnancy. F. Anim. Sci. 18, 675.

FinNey, D. J. (1964) The use of concomitant information. In: Statistical Methods in Biological Assay, p. 325. Hafner, New York.

GARDNER, W. U. \& TURNER, C. W. (1933) The function, assay and preparation of galactin, a lactation stimulating hormone of the anterior pituitary and an investigation of the factors responsible for the control of normal lactation. Res. Bull. Mo. agric. Exp. Stn. 196, 20.

Grosvenor, C. E. \& Turner, C. W. (1958) Assay of lactogenic hormone. Endocrinology, 63, 530.

Mertes, J. \& Turner, C. W. (1950) Lactogenic hormone. In: Hormone Assay, p. 237. Ed. C. W. Emmens. Academic Press, New York.

Nagasawa, H., Chen, C. L. \& Meites, J. (1969) Effects of estrogen implant in median eminence on serum and pituitary prolactin levels in the rat. Proc. Soc. exp. Biol. Med. 132, 859.

Ratner, A., Talwalker, P. K. \& Meites, J. (1963) Effects of estrogen administration in vivo on prolactin release by rat pituitary in vitro. Proc. Soc. exp. Biol. Med. 112, 12.

REECE, R. P. \& TURNER, G. W. (1936) Influence of estrone upon galactin content of male rat pituitaries. Proc. Soc. exp. Biol. Med. 34, 402.

Snedecor, G. W. \& Cochran, W. G. (1968) One-way classification. Analysis of variance. In: Statistical Methods, p. 258. Iowa State University Press, Ames, Iowa.

Stricker, P. \& GrUeter, F. (1928) Action du lobe antérieur de l'hypophyse sur la monté Elaiteuse. C. r. Séanc. Soc. Biol. 99, 1978.

Voogt, J. L., Glemens, J. A. \& Mertes, J. (1969) Stimulation of pituitary Fsh release in immature female rats by prolactin implant in median eminence. Neuroendocrinology, 4, 157. 